\title{
The Utilize of Vermicomposting Outputs in Substrate Culture for Producing Snap Bean
}

\author{
F. A. AboSedera ${ }^{1}$, Nadia. S. Shafshak ${ }^{1}$, A. S. Shams ${ }^{1}$, M. A. Abul-Soud ${ }^{2}$, M. H.Mohammed ${ }^{2}$. \\ 1- Hort. Dept. Fac. Agric, Mochtohor. Benha University. \\ 2- Close Agriculture Methods Research Dept, Central Laboratory for Agriculture Climate, Agriculture Research \\ Center
}

\begin{abstract}
The need for increasing the agricultural area to secure food production and the sustainability under the climate change impacts and current conditions of Egypt, especially the shortage of available water and soil were the driving forces for developing ecology substrate culture via using vermicomposting outputs. The study was carried out at Central Laboratory for Agricultural Climate (CLAC), Giza, Egypt under unheated double span plastic house during two successive autumn seasons of 2012/2013 and 2013/2014 for investigating the effect of vermicompost as substrate amendment mixed with perlite or sand in different proportions $0,10,20$ and $30 \%$ of substrate combined with three sources of nutrient solutions (compost tea, vermi-liquid and chemical) on the growth and yield of snap bean $c v$. Alhamma in split plot design with four replicates.

Data revealed that increasing vermicompost rate from 0 to $20 \%$ had positive significant effects on vegetative growth, yield and quality of snap bean pods while increasing the rate up to $30 \%$ had no subsequent effect. Sand + vermicompost $(80: 20 \mathrm{v} / \mathrm{v})$ followed by perlite + vermicompost $(80: 20 \mathrm{v} / \mathrm{v})$ recorded the highest results of the vegetative growth characteristics during the two successive seasons compared to other treatments. The highest values of early and total yield $/ \mathrm{m}^{2}$ were recorded by sand + vermicompost (80:20 v/v) 1494 and $6947 \mathrm{~g} / \mathrm{m}^{2}$ during the first season, respectively. In addition, it recorded the highest early yield on the second season $\left(1552 \mathrm{~g} / \mathrm{m}^{2}\right)$. While treatment of sand + vermicompost $(70: 30 \mathrm{v} / \mathrm{v})$ recorded the highest total yield $\left(7035 \mathrm{~g} / \mathrm{m}^{2}\right)$. Otherwise, obtained results of the effect of nutrient solution sources indicated that the chemical nutrient solution recorded the highest vegetative growth traits and yield characteristics. Perlite + vermicompost $(70: 30 \mathrm{v} / \mathrm{v})$ combined with chemical nutrient solution had the highest results of early (1605) and total yield (7734) $\left(\mathrm{g} / \mathrm{m}^{2}\right)$.

The study supports the use of vermicompost as substrate amendment and compost tea and vermi-liquid as a source of nutrient solution in ecology soilless production of snap bean plants. The environmental impacts of vermicomposting could create sustainable source of organic substrate and fertilizer besides mitigating $\mathrm{CO}_{2}$ emission.
\end{abstract}

Keywords: Vermicompost, Vermi-Liquid, Compost Tea, Nutrient Solution, Substrate Culture, Perlite, Sand, Vegetative Growth, Yield and Snap Bean.

\section{Introduction}

Snap bean (Phaseolus vulgaris L.) is one of the most important pulse and fresh market crop in the world and it is also one of the most important legume crops in Egypt cultivated for local consumption as well as exportation especially during the period from December to May. However, it is highly sensitive to environmental conditions (climate, salinity, irrigation, fertilization etc...). It is an important source of proteins, calories, dietary fibers, minerals and vitamins for millions of people in both developing and developed countries worldwide. The acreage of snap bean in Egypt was 57873 fed. in 2012, and produced 251279 tons according to the Statistics of Ministry of Agriculture 2013.

Widely used substrate components include peat moss, pine bark, perlite, vermiculite, sand; etc. The need to produce local substrate instead of imported substrates drives many researchers to develop different substrate to play the role of peat moss. Several studies revealed that peat can be substituted by various compost types without any negative effects on a variety of crops raised in these substrates (Hashemimajd $\boldsymbol{e t}$ al., 2004). On the other hand, the commercial soilless culture progress slowly while it's expected to grow so fast through the next years according to the increase demands for food security. The expected future of climate change impacts and water shortage will be the driving forces to pay more attention for soilless culture. In this respect, Surrage et al., (2010) reported that Forterra Royal GRO1 (coconut coir/vermicompost) and Forterra Royal GRO2 (aged pine bark/coconut coir/vermicompost) attained signifiantly higher marketable yields per tomato plant compared with the plants grown in rockwool.

Vermicomposting has been discussed as a key step in sustainable Organic Solid Wastes (OSW) 
management, in many countries like Germany (Ernst et al., 2008), Spain (Monroy et al., 2009), USA (Arancon et al., 2008) and Vietnam (Yadav et al., 2010).

Vermicompost could be used as a natural fertilizer having a number of advantages over chemical fertilizers, possibly due to better physical properties, higher microbial and enzymatic activity and higher content of available nutrients. Producer acceptance of vermicompost is greater than that of compost (Venugopal et al., 2010 and Abul-Soud et al., 2014b). Quaik et al., 2012b indicated that, vermicomposting has been getting attention due to its environmental friendly approach. Beside the compost produced, recent interest has been brought up due to the possible use of the liquid by products from this green technology. Different organic wastes can be used in vermicompost production by different species of earthworms which include horse waste ( Garg and Kaushik, 2005); cattle dung (Quaik et al, 2012a); urban solid waste (Singh $\boldsymbol{e t}$ al, 2010); city leaf litter and food wastes (Nath $\boldsymbol{e t} \boldsymbol{a l}, \mathbf{2 0 0 9}$ ); paper waste and residues of plant decomposition (Abul-Soud et al., 2009). Vermicompost has a significant positive influence on seed germination and seedling vigor, plant growth, flowering, fruiting, tuberization, root development, colour, shelf-life and quality of vegetables (Suthar 2009 and Chanda et al. 2011).

Several studies assessed the effect of vermicompost amendments in potting substrates on seedling emergence and growth of a wide range of marketable fruits cultivated in greenhouses, as well as on growth, yields of green gram (Phaseolus aurus Roxb) (Kamergam et al., 1999). Providing that all nutrients are supplied by mineral fertilization, studies show greatest plant growth responses when vermicompost constituted a relatively small proportion (10 to $20 \%$ ) of the total volume of the substrate mixture, with higher proportions of vermicomposts in the mixture not always improving plant growth (Atiyeh et al., 2000b).

Extract from vermicompost is known as vermicompost extract. Vermicomposting derived liquids contain valuable nutrients that promote plant growth. Substrates that have been used in these liquids production are mainly animal and agricultural waste. (Gutiérrez-Miceli et al, 2011 and Pant et al, 2009). Available plant nutrients that present in these liquids are valuable and have the potential to be used as nutrients solution in hydroponics culture. Quaik et al, 2012b reported that vermicomposting leachate, this biofertilizer showing promising results in various dilutions on Radish (Raphanus sativus L.) germination $(\%)$, number of leaves, plant height and shoot dry weight are highest in leachate of $10 \%$ dilution, whereas root dry weight is highest in leachate of 15\% dilution (Gutiérrez-Miceli et al, 2011).

Compost tea is liquid extracted or leached from compost. It will contain soluble nutrients, both organic and inorganic, and microorganisms, including bacteria, fungi, protozoa, and nematodes. The benefit of tea supplies depends on what can be extracted from the compost (Scheuerell and Mahaffee, 2002). Diver (2002) indicated that compost teas and herbal teas are tools that can be made on the farm to enhance crop fertility and to inoculate the phyllosphere and rhizosphere with soluble nutrients, beneficial microbes, and the beneficial metabolites of microbes. Abou-ElHassan et al. (2008) reported that compost tea as organic nutrient solution can substitute the inorganic nutrient solution to cantaloupe production in nutrient film technique.

The main objectives of the current study were to assess ecology soilless culture under Egyptian condition, to investigate the use of vermicomposting outputs on snap bean production and to minimize the environmental impacts of soilless culture inputs (peat moss and chemical fertilizers and to mitigate $\mathrm{CO}_{2}$ emission).

\section{Material and Methods}

This experiment was conducted in the experimental station at the Central Laboratory for Agricultural Climate (CLAC), Agriculture Research Center (ARC), Egypt, during the autumn seasons of 2012/2013 and 2013/2014 under unheated double span plastic house (18 x $60 \times 4.5 \mathrm{~m})$.

\section{Plant material:}

Snap bean seeds $c v$. Alhamma were sown on $4^{\text {th }}$ week of September in both cultivated seasons. Three seeds of snap bean were planted directly in pots.

\section{The vermicomposting process:}

Epigiec earthworms imported from Australia, Lumbriscus rubellus (Red Worm), Eisenia fetida (Tiger Worm), Perionyx excavatus (Indian Blue) and Eudrilus eugeniae (African Night Crawler) were used in the vermicomposting beds system under this study. According to (Ernst et al., 2008; Abul-Soud et al., 2009 and Venugopal et al., 2010) fife $\mathrm{kg}$ of epigiec earthworms were taken and placed in each bed system. Worm diameter: $0.5-5 \mathrm{~mm}$ and worm length: $10-$ $120 \mathrm{~mm}$. Bed system of vermicomposting was used in this investigation for producing the vermicompost and vermi-liquid. Eight Beds were established under black net house by digging the soil and mulched with black polyethylene plastic sheet $0.5 \mathrm{~mm}$ to perform a bed with length $2.5 \mathrm{~m}$, width $1.2 \mathrm{~m}$ and depth $50 \mathrm{~cm}$. A slope $1.5 \%$ had been done to collect the vermin-liquid 
through water bucket. Mixing the different raw materials: cattle manure $(\mathrm{C} . \mathrm{M})+$ vegetable and fruit wastes $(\mathrm{V}$. F. W) + shredded paper (Sh. P) in the rate of 2: 2: $1(\mathrm{v} / \mathrm{v})$ respectively was done by using turning machine and pre-composting of different raw materials for 7 to 10 days before feed it to worms to avoid the thermophilic stage (increase temperature above $35^{\circ} \mathrm{C}$ cause the death of earthworms in vermicompost systems). After pre-composting done, The final mix soaked in water for $1 / 2$ to 1 hour to make sure it is not drier and put it in lines along the bed. The compositions of the different organic wastes are presented in Table 1. The feeding of earthworm done every two days and every 21 days the earthworms were fasting for 7 days to give them the opportunities to reeat the cast and to avoid non composted wastes. Moisture content was in the range of $60-70 \%$.

\section{The study treatments:}

Four different rates of vermicompost (V) mixed with sand $(\mathrm{S})$ or perlite $(\mathrm{P})$ in different proportions as follows: $0,10,20$ and $30 \%(v / v)$ combined with chemical nutrient solution (control), compost tea and vermi-liquid as sources of nutrient solution to present 24 treatments.

The experimental design was a spilt-plot design with 4 replicates. The sources of nutrient solutions were assigned as main plots and vermicompost rates as subplots.

\section{System materials:}

Plastic pots $8 \mathrm{~L}$ ( $25 \mathrm{~cm}$ diameter x $30 \mathrm{~cm}$ height) were used, the pots were filled by different substrate mixes and placed in two rows in open substrate system. The pots arranged in two rows per bed. The final plant spacing was $50 \mathrm{~cm}$ in the row, $40 \mathrm{~cm}$ between the rows, and $90 \mathrm{~cm}$ in between the double rows.

The stock nutrient solutions of compost teas were prepared by soaking 41 from compost in 201 of water (1:5 by volume), the brewing of the compost occurring after 24 hours to get the concentrated compost tea. The concentrated compost tea was filtrated to get the clear solution, and then used to prepare the nutrient solution by diluting this stock up to 1201 water in solution tank. According to Abou-El-Hassan et al., (2008).

The vermi-liquid was collected through vermicomposting process. The vermi-liquid filtered by using nets to remove any residues or dust that could cause blocking of drippers before diluted to the desire EC.

Different nutrient solutions pumped via submersible pump (110 watt). Water tanks $120 \mathrm{~L}$ were used in open system of substrate pots culture. The nutrient solution used in the experiment was adapted from Cooper, (1979) depending on the analysis of the local water by El-Behairy, (1994). Plants were irrigated by using drippers of $4 \mathrm{l} / \mathrm{hr}$ capacity. The fertigation was programmed to work 8 times / day and the duration of irrigation time depended upon the season. The EC of the different nutrient solutions were adjusted by using EC meter to the required level (2.5 mmhos $\left.{ }^{-1}\right)$. The chemical compositions of vermi-liquid and chemical nutrient solution were illustrated in Table 3. Substrate physical properties i.e. bulk density (B.D), total pore space (T.P.S), water hold capacity \% (W.H.C) and air porosity \% (A.P) were estimated according to Wilson (1983) and Raul (1996). The $\mathrm{pH}$ of the potting mixtures were determined using a double distilled water suspension of each potting mixture in the ratio of 1:10 (w: v) (Inbar et al., 1993) that had been agitated mechanically for $2 \mathrm{~h}$ and filtered through Whatman no.1 filter paper. The same solution was measured for electrical conductivity with a conductance meter that had been standardized with 0.01 and $0.1 \mathrm{M} \mathrm{KCl}$.

Samples of three plants of each experimental plot were taken to determine growth parameters at 120 days from the sowing as follows: Plant height, Total leaf area/plant was recorded using a digital leaf area meter (LI-300 portable area meter produced by LI-COR, Lincoln, Nebraska, USA), Total plant fresh and dry weight (Total dry weight was determined after ovendrying the samples at $70{ }^{\circ} \mathrm{C}$ for 48 hours), Yield measurements: early and total yield, physical properties for pods i.e., average pod length, diameter and weight. For mineral analysis of samples $(\mathrm{N}, \mathrm{P}$ and $\mathrm{K})$, three plant leaves samples of each plot were dried at $70^{\circ} \mathrm{C}$ in an air forced oven for $48 \mathrm{~h}$. and dried leaves were digested in $\mathrm{H}_{2} \mathrm{SO}_{4}$ according to the method described by Allen (1974) and N, P and $\mathrm{K}$ contents were estimated in the acid digested solution. Total nitrogen was determined by Kjeldahl method according to the procedure described by FAO (1980). Phosphorus content was determined using spectrophotometer according to Watanabe and Olsen (1965).

Table 1. The chemical composition (\%) of the different agricultural wastes

\begin{tabular}{lcccccc}
\hline Raw material & C/N ratio & \multicolumn{5}{c}{ Macro elements \% } \\
\cline { 3 - 6 } & & $\mathrm{N}$ & $\mathrm{P}$ & $\mathrm{k}$ & $\mathrm{Ca}$ & $\mathrm{Mg}$ \\
\hline C. $M$ & 22.00 & 1.83 & 0.56 & 1.38 & 1.13 & 1.06 \\
V. $F$. . & 62.60 & 0.34 & 0.19 & 0.64 & 0.81 & 0.43 \\
Sh. $P$ & 166.81 & 0.016 & 0.01 & 0.00 & 0.20 & 0.01 \\
The mix & 67.26 & 0.90 & 0.31 & 0.73 & 0.81 & 0.59 \\
\hline
\end{tabular}


Table 2. The physical and chemical properties of vermicompost

\begin{tabular}{cccccc}
\hline Analysis & UNITS & T.P.S \% & Analysis & UNITS & T.P.S \% \\
\hline B.D & $\mathrm{Kg} / \mathrm{m}^{3}$ & 715 & $\mathrm{P}$ & $\%$ & 1.27 \\
O. M & $\%$ & 33.22 & $\mathrm{~K}$ & $\%$ & 0.59 \\
C/N ratio & & $1: 12.27$ & $\mathrm{Fe}$ & $\mathrm{ppm}$ & 802 \\
pH & & 8.17 & $\mathrm{Mn}$ & $\mathrm{ppm}$ & 143 \\
EC & $\mathrm{dS} / \mathrm{m}$ & 6.67 & $\mathrm{Zn}$ & $\mathrm{ppm}$ & 37.0 \\
N & $\%$ & 1.57 & $\mathrm{Cu}$ & $\mathrm{ppm}$ & 14.0 \\
N-NH4 & $\mathrm{ppm}$ & 65 & $\mathrm{~Pb}$ & $\mathrm{ppm}$ & 9.0 \\
N-NO3 & $\mathrm{ppm}$ & 81 & $\mathrm{Cd}$ & $\mathrm{ppm}$ & n.d. \\
\hline
\end{tabular}

Table 3. The chemical composition of different sources of nutrient solutions

\begin{tabular}{lccccccccccccc}
\hline \multirow{2}{*}{ Nutrient source } & \multicolumn{4}{c}{ Macro nutrients ppm } & \multicolumn{1}{c}{ Micro nutrients ppm } \\
\cline { 2 - 14 } & $\mathrm{N}$ & $\mathrm{P}$ & $\mathrm{K}$ & $\mathrm{Ca}$ & $\mathrm{Mg}$ & $\mathrm{Fe}$ & $\mathrm{Mn}$ & $\mathrm{Zn}$ & $\mathrm{Cu}$ & $\mathrm{B}$ & $\mathrm{Pb}$ & $\mathrm{Cd}$ \\
\hline Compost tea & 162 & 187 & 275 & 99 & 38 & 0.68 & 0.02 & 0.02 & 0.02 & 0.27 & 0.012 & n.d \\
Vermi-liquid & 128 & 181 & 322 & 111 & 48.6 & 0.25 & 0.04 & 0.01 & 0.04 & 0.21 & 0.047 & n.d \\
Chemical & 250 & 45 & 350 & 180 & 50 & 3.0 & 1 & 0.06 & 0.10 & 0.25 & 0.157 & 0.014 \\
\hline
\end{tabular}

Potassium content was determined photometrically using Flame photometer as described by Chapman and Pratt (1961). The obtained data were statistically analyzed using the analysis of variance method according to Snedecor and Cocharn (1980). Duncan's multiple range tests at the $5 \%$ level of probability was used to compare means of treatments.

\section{Results and Discussion}

3.3 The effect of vermicompost rate and nutrient solution source on:

3.3.1The physical and chemical properties of different substrate mixtures:

The physical and chemical properties of different substrates mixtures for experiments are illustrated in Table 4. The obtained data indicated that increasing the rate of vermicompost from 0 to $30 \%$ led to decrease the B.D and A.P of sand mixtures while T.P.S and W.H.C were increased. On the other hand, B.D and W.H.C were increased and T.P.S and A.P were decreased by increasing the vermicompost rate from 0 to $30 \%$ in perlite mixtures.

The results of physical properties of sand and perlite mixtures presented clear contrast as a result of different rate of vermicompost application. The lowest B.D of perlite as well as W.H.C of sand are undesirable properties due to the vertical growth of snap bean that need to more stability and support with optimum moisture content respectively.

the bulk density of vermicompost is usually higher and the particle size lower than in some of the most commonly used peat-based substrates, mixing of these two substrates produces a significant increase in the bulk density and water holding capacity, while decreasing particle size and total porosity Atiyeh $\boldsymbol{e t}$ al, (2001); Bachman and Metzger, (2007). Hidalgo et al,
(2006) reported a significant increase in T.P.S and WHC after addition of vermicompost to a greenhouse potting medium comprising a mixture of sand, pine bark and peat. Limited studies on vermicompost indicated that it increases macropore space ranging from 50 to $500 \mu \mathrm{m}$, resulting in improved air-water relationship in the soil which favorably affects plant growth; the application of organic matter including vermicompost favorably affects soil $\mathrm{pH}$, microbial population and soil enzyme activities (Karuna et al., 2011). Veerabhadraiah et al, (2006) showed improved soil properties due to application of vermicompost.

As a result of increasing vermicompost rate in both of sand and perlite from 0 to $30 \%$, E.C and O.M were increased regarding to the increase of organic compounds and high nutrient contents. The highest values of E.C and O.M were given by apply $30 \%$ vermicompost rate in both of sand and perlite mixture as illustrated in Table 4. These results agreed with Atiyeh et al., (2001). While the increase in vermicompost rate led to a slight increase in $\mathrm{pH}$, especially with the perlite. Most of these results regarding physical and chemical properties are consistent with (Gutie'rrez-Miceli et al., 2007 and Manivannan et al., 2007). Regarding to the chemical properties (EC and $\mathrm{pH}$ ), the obtained data indicated that increasing the rate of vermicompost led to increase $\mathrm{EC}$ and $\mathrm{pH}$ of different mixtures as a result of high contents of nutrients of vermicompost (Venugopal $\boldsymbol{e t}$ al., 2010 and Abul-Soud et al., 2014b). The current study focus on the organic soil matter content as a strong indicator while much of the research on vermicompost has focused on studying plant available nutrients and changes in soil structure via soil porosity, aeration, and moisture holding capacity. (Hashemimajd et al., 2004 and Tejada et al., 2010) 
Table 4. The physical and chemical properties of different substrates mix of study.

\begin{tabular}{cccccccc}
\hline & \multicolumn{3}{c}{ Physical } & \multicolumn{3}{c}{ Chemical } \\
\hline Substrate & $\begin{array}{c}\text { B.D } \\
\text { Kg/l }\end{array}$ & T.P.S \% & W.H.C \% & $\begin{array}{c}\boldsymbol{A . P} \\
\text { \% }\end{array}$ & $\begin{array}{c}\boldsymbol{E} . \boldsymbol{C} \\
\text { mmhos-1 }\end{array}$ & $\boldsymbol{p H}$ & $\boldsymbol{O} . \boldsymbol{M \%}$ \\
\hline Sand 100\% & 1.67 & 26.0 & 17.8 & 8.2 & 0.4 & 7.6 & 0.20 \\
S 90\%:VC10 & 1.60 & 32.7 & 26.4 & 6.3 & 0.61 & 7.7 & 1.188 \\
S 80\%:VC20 & 1.56 & 37.2 & 33.1 & 4.1 & 0.90 & 7.8 & 2.436 \\
S 70\%:VC30 & 1.52 & 43.1 & 39.5 & 3.6 & 1.07 & 7.8 & 3.750 \\
perlite 100\% & 0.125 & 90.0 & 30.5 & 59.5 & 0.34 & 7.4 & 0.00 \\
P 90\%:VC10 & 0.239 & 85.7 & 36.8 & 48.9 & 0.76 & 7.6 & 7.951 \\
P 80\%:VC20 & 0.341 & 78.6 & 43.3 & 35.3 & 1.05 & 7.8 & 11.145 \\
P 70\%:VC30 & 0.430 & 74.5 & 48.5 & 26.0 & 1.21 & 7.9 & 13.257 \\
\hline
\end{tabular}

\subsubsection{Vegetative growth parameters and production} of snap bean:

Table 5 presented the effect of nutrient solution sources and substrate mixtures on the vegetative growth of snap bean. Regarding to the effect of nutrient solution source, chemical nutrient solution (N.S) was gave the highest values of plant height, leaf area, number of shoot, fresh and dry weight per plant, while the lowest values was gaven by compost tea (T.C), with no significant different between vermi-liquid (V.L) and compost tea in both seasons of study.

Application of vermicompost to sand and perlite mixtures resulted in promotion vegetative growth parameters in general. Adding vermicompost at $20 \%$ tended to increase the plant height, leaf area, fresh and dry weight per plant as well as number of shoot meanwhile, increasing the rate at $30 \%$ vermicompost was ineffective in both seasons with either sand or perlite mixtures as well.

As for the interaction effect between nutrient solution source and substrate mixture, data in Table 5 show that sand + vermicompost $(80+20 v / v)$ combined with chemical nutrient solution gave the highest significant results of plant height, fresh and dry weight per plant. The highest value of leaf area was recorded by sand and perlite with vermicompost rate $(80+20$ $v / v)$. On the other hand, the lowest values were recorded by $0 \%$ vermicompost with slight significant differences between sand and perlite mixtures with all nutrient sources in both two seasons of growth. While the interaction effect on number of shoot was not clear through increasing vermicompost rates from 10 to 30 $\%$ combined with all nutrient sources solutions.

These results are in agreement with those mentioned by Singh and Chauhan, 2009; Roy et al., (2010) and Fernández-Luqueño $F$ et al., (2010) on common bean (Phaseolus vulgaris.L) plants. As affirmed by Rasool et al., 2009 on cucumber (Cucumis sativus L.). Senthilkumar et al., (2004) found that vermicompost \pm NPK fertilizers significantly enhanced rose growth, yield and quality over the untreated control, especially when used in combination.
3.3.3 Chemical composition of snap bean leaves:

The presented data in Table 6 indicate the effect of nutrient solution sources and substrate mixtures as well as their interaction on the chemical composition of snap bean leaves.

As the result of Table 6 illustrate that the different tested nutrient solution i.e., chemical nutrient solution, compost tea and vermi-liquid had no significant effect on the $\mathrm{K}$ content during the two seasons of study. While, data show that using chemical solution reflected the highest values in $\mathrm{N}$ and $\mathrm{P}$ content. On the contrary, vermi-liquid as a nutrient solution led to the lowest results of $\mathrm{P}$ during the two seasons of growth.

Increasing the vermicompost rate from 10 to $30 \%$ with sand did not affect the N content, while, applied $10 \%$ vermicompost rate in perlite mixtures led to the highest value of $\mathrm{N}$ content in leaves. But increasing vermicompost rate up to 20 or $30 \%$ tend to decrease the content of $\mathrm{N}$. The highest values of both $\mathrm{P}$ and $\mathrm{K}$ content were recorded by perlite + vermicompost $(90+10 \mathrm{v} / \mathrm{v})$, and the lowest value was recorded by sand plus 30\% vermicompost in both mixtures with significant difference. Concerning, the combination between different nutrient solution and substrates, the same data show that chemical nutrient solution with perlite mixtures with vermicompost rate $(90+10 \mathrm{v} / \mathrm{v})$ gave the highest values in N and P content (Datt et al., 2013). While the same substrate mixture with vermiliquid reflected the highest potassium content. Similar resulted were reported by Sharma et al., 2008. The lowest $\mathrm{N}$ content values were by vermicompost rate $(80+20 v / v)$ and vermicompost rate $(70+30 v / v)$ combined with vermi-liquid in first and second season respectively with no significant different, but, the lowest value of $\mathrm{P}$ content was recorded by sand + vermicompost $(70+30 \mathrm{v} / \mathrm{v})$ combined with vermiliquid. While, the highest value of $\mathrm{K}$ content was recorded by vermi-liquid combined with perlite + vermicompost $(90+10 v / v)$ in first season but sand $100 \%$ and perlite + vermicompost $(90+10 v / v)$ in the second one, respectively. These results agree with Abul-Soud et al., (2014a) on peas. 
Table 5. Effect of different nutrient solution and different substrates and their interaction on growth characteristics of snap beans plants during 2012 / 2013 and 2013 / 2014 seasons.

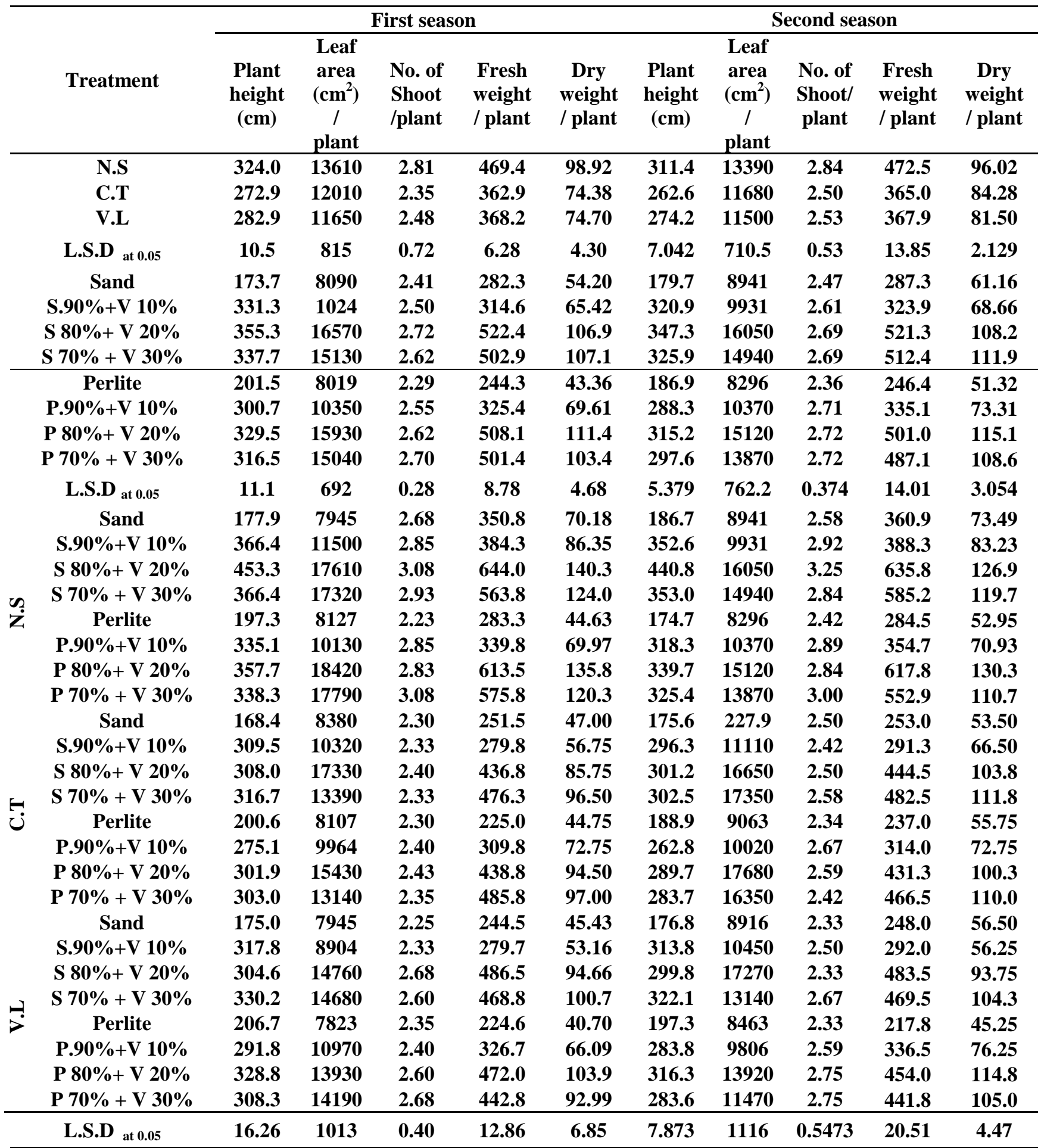

Sand $90 \%$ : vermicompost $10 \%$, sand $80 \%$ : vermicompost $20 \%$, sand $70 \%$ : vermicompost $30 \%$, perlite $90 \%$ : vermicompost $10 \%$, perlite $80 \%$ : vermicompost $20 \%$, perlite $70 \%$ : vermicompost $30 \%$. 
Table 6. Effect of different nutrient solution and different substrates and their interaction on chemical composition of snap bean leaves during 2012-2013 and 2013-2014 seasons.

\begin{tabular}{|c|c|c|c|c|c|c|c|}
\hline & \multirow{2}{*}{ Treatment } & \multicolumn{3}{|c|}{ First season } & \multicolumn{3}{|c|}{ second season } \\
\hline & & $\mathbf{N}$ & $\mathbf{P}$ & $\mathbf{K}$ & $\mathbf{N}$ & $\mathbf{P}$ & $\mathbf{K}$ \\
\hline & N.S & 2.96 & 0.458 & 2.23 & 2.84 & 0.456 & 2.18 \\
\hline & C.T & 2.54 & 0.417 & 2.26 & 2.54 & 0.416 & 2.18 \\
\hline & V.L & 2.71 & 0.353 & 2.22 & 2.63 & 0.357 & 2.14 \\
\hline & L.S.D at 0.05 & 0.163 & 0.048 & n.s & 0.083 & 0.340 & n.s \\
\hline & Sand & 2.70 & 0.377 & 2.37 & 2.64 & 0.372 & 2.31 \\
\hline & $\mathrm{S} .90 \%+\mathrm{V} 10 \%$ & 2.46 & 0.341 & 2.22 & 2.22 & 0.349 & 2.13 \\
\hline & S $80 \%+$ V $20 \%$ & 2.46 & 0.370 & 2.39 & 2.42 & 0.366 & 2.28 \\
\hline & S 70\% + V 30\% & 2.41 & 0.305 & 1.99 & 2.38 & 0.315 & 1.90 \\
\hline & Perlite & 2.86 & 0.455 & 2.25 & 2.82 & 0.459 & 2.22 \\
\hline & $P .90 \%+V 10 \%$ & 3.25 & 0.534 & 2.52 & 3.22 & 0.520 & 2.34 \\
\hline & P $80 \%+$ V $20 \%$ & 2.94 & 0.488 & 2.38 & 2.96 & 0.491 & 2.34 \\
\hline & P $70 \%+V 30 \%$ & 2.81 & 0.404 & 1.77 & 2.70 & 0.405 & 1.85 \\
\hline & L.S.D at 0.05 & 0.183 & 0.031 & 0.374 & 0.146 & 0.031 & 0.053 \\
\hline & Sand & 2.35 & 0.300 & 2.54 & 2.43 & 0.308 & 2.46 \\
\hline & S.90\%+V $10 \%$ & 2.55 & 0.318 & 2.30 & 2.32 & 0.326 & 2.15 \\
\hline & S $80 \%+$ V $20 \%$ & 2.53 & 0.445 & 2.43 & 2.37 & 0.431 & 2.35 \\
\hline ?ִ & S 70\% + V 30\% & 2.43 & 0.283 & 1.91 & 2.47 & 0.316 & 1.96 \\
\hline$\dot{z}$ & Perlite & 2.94 & 0.556 & 2.24 & 2.81 & 0.543 & 2.19 \\
\hline & P.90\%+V 10\% & 3.84 & 0.773 & 2.32 & 3.62 & 0.707 & 2.25 \\
\hline & P $80 \%+$ V $20 \%$ & 3.58 & 0.536 & 2.39 & 3.43 & $\mathbf{0 . 5 5 3}$ & 2.34 \\
\hline & P 70\% + V 30\% & 3.45 & 0.456 & 1.74 & 3.28 & 0.466 & 1.77 \\
\hline & Sand & 3.14 & 0.531 & 2.40 & 3.16 & 0.502 & 2.38 \\
\hline & S.90\%+V $10 \%$ & 2.47 & 0.411 & 2.27 & 2.10 & 0.420 & 2.16 \\
\hline & S $80 \%+$ V $20 \%$ & 2.49 & 0.364 & 2.39 & 2.59 & 0.374 & 2.29 \\
\hline F & S $70 \%+V 30 \%$ & 2.49 & 0.399 & 1.83 & 2.48 & 0.383 & 1.84 \\
\hline$\tau^{j}$ & Perlite & 2.68 & 0.453 & 2.33 & 2.65 & 0.463 & 2.24 \\
\hline & P.90\%+V 10\% & 2.65 & 0.350 & 2.61 & 2.71 & 0.362 & 2.34 \\
\hline & P $80 \%+$ V 20\% & 2.21 & 0.440 & 2.48 & 2.48 & 0.446 & 2.41 \\
\hline & P 70\% + V 30\% & 2.21 & 0.386 & 1.76 & 2.14 & 0.379 & 1.83 \\
\hline & Sand & 2.60 & 0.301 & 2.18 & 2.33 & 0.308 & 2.08 \\
\hline & $\mathbf{S . 9 0 \% + V ~} 10 \%$ & 2.38 & 0.294 & 2.09 & 2.25 & 0.301 & 2.07 \\
\hline & S $80 \%+$ V $20 \%$ & 2.37 & 0.302 & 2.37 & 2.29 & 0.293 & 2.20 \\
\hline بـ & S $70 \%+V 30 \%$ & 2.31 & 0.232 & 2.25 & 2.18 & 0.246 & 1.92 \\
\hline$>$ & Perlite & 2.97 & 0.358 & 2.19 & 3.00 & 0.370 & 2.22 \\
\hline & P.90\%+V 10\% & 3.26 & 0.481 & 2.63 & 3.32 & 0.491 & 2.44 \\
\hline & P $80 \%+$ V $20 \%$ & 3.04 & 0.488 & 2.27 & 2.98 & 0.474 & 2.27 \\
\hline & P 70\% + V 30\% & 2.78 & 0.369 & 1.83 & 2.66 & $\mathbf{0 . 3 7 2}$ & 1.96 \\
\hline & L.S.D at 0.05 & 0.268 & 0.0448 & 0.547 & 0.214 & 0.0447 & 0.0774 \\
\hline
\end{tabular}

Sand $90 \%$ : vermicompost $10 \%$, sand $80 \%$ : vermicompost $20 \%$, sand $70 \%$ : vermicompost $30 \%$, perlite $90 \%$ : vermicompost $10 \%$, perlite $80 \%$ : vermicompost $20 \%$, perlite $70 \%$ : vermicompost $30 \%$.

Moreover, (Kumari and Ushakumari, 2002 and Quaik et al., 2012a) found that treatment with enriched vermicompost was superior to other treatments for the uptake of $\mathrm{N}, \mathrm{P}, \mathrm{K}, \mathrm{Ca}$ and $\mathrm{Mg}$ by cowpea. Vermicompost contain nutrients in forms that are readily taken up by the plants such as nitrates, exchangeable phosphorus, and soluble potassium, calcium, and magnesium.
Data in Table (7) indicate the effect of different studied nutrient solution and substrates as well as their interaction on green pods yield and its physical traits expressed as average pod weight, length and diameter during both season of growth.

Concerning the effect on nutrient solution, the same data in Table 7 show that there were significant differences in all determined yield parameters i.e., 
early and total pods yield / $\mathrm{m}^{2}$ and produced pods quality (average pod weight, length and diameter) as a result of tested nutrient solution sources (chemical nutrient solution, compost tea and vermi-liquid) during both seasons of growth. In this concern, using chemical nutrient solution reflected the highest values in early and total yield as well as pods physical quality traits followed by using compost tea and vermi-liquid in descending order during the two seasons of growth.

Table 7. Effect of different nutrient solution and different substrates and their interaction on yield quality characteristics of snap beans plants during 2012 / 2013 and 2013 / 2014 seasons.

\begin{tabular}{|c|c|c|c|c|c|c|c|c|c|c|c|}
\hline \multirow{2}{*}{\multicolumn{2}{|c|}{ Treatment }} & \multicolumn{9}{|c|}{ First season } & \multirow[b]{2}{*}{$\begin{array}{c}\text { Pod } \\
\text { weight } \\
\text { (g) } \\
\end{array}$} \\
\hline & & $\begin{array}{l}\text { Early } \\
\text { yield } \\
\mathrm{g} / \mathrm{m}^{2} \\
\end{array}$ & $\begin{array}{l}\text { Total } \\
\text { yield } \\
\mathrm{g} / \mathrm{m}^{2} \\
\end{array}$ & $\begin{array}{c}\text { Pod } \\
\text { length } \\
(\mathrm{cm}) \\
\end{array}$ & $\begin{array}{c}\text { Pod } \\
\text { diameter } \\
(\mathbf{c m})\end{array}$ & $\begin{array}{c}\text { Pod } \\
\text { weight } \\
\text { (g) }\end{array}$ & $\begin{array}{l}\text { Early } \\
\text { yield } \\
\mathrm{g} / \mathrm{m}^{2} \\
\end{array}$ & $\begin{array}{l}\text { Total } \\
\text { yield } \\
\mathrm{g} / \mathrm{m}^{2} \\
\end{array}$ & $\begin{array}{c}\text { Pod } \\
\text { length } \\
(\mathrm{cm}) \\
\end{array}$ & $\begin{array}{c}\text { Pod } \\
\text { diameter } \\
(\mathrm{cm})\end{array}$ & \\
\hline & N.S & 1306 & 6270 & 14.00 & 0.78 & 5.68 & 1390 & 6371 & 13.81 & 0.77 & 6.09 \\
\hline & C.T & 1212 & 5444 & 13.59 & 0.73 & 5.33 & 1232 & 5487 & 13.41 & 0.73 & 5.53 \\
\hline & V.L & 1145 & 5625 & 13.69 & 0.73 & 5.28 & 1154 & 5824 & 13.50 & 0.73 & 5.37 \\
\hline & L.S.D at 0.05 & 68 & 194 & 0.35 & 0.06 & 0.12 & 184 & 261 & 0.36 & 0.03 & 0.123 \\
\hline & Sand & 728.0 & 3872 & 13.79 & 0.72 & 4.96 & 748.7 & 4155 & 13.31 & 0.74 & 5.08 \\
\hline & $\mathrm{S} .90 \%+\mathrm{V} 10 \%$ & 1421 & 6368 & 13.42 & 0.75 & 5.59 & 1477 & 6570 & 13.32 & 0.77 & 5.73 \\
\hline & S $80 \%+$ V $20 \%$ & 1494 & 6947 & 13.52 & 0.76 & 5.48 & 1552 & 6897 & 13.55 & 0.74 & 6.01 \\
\hline & $\mathrm{S} 70 \%+\mathrm{V} 30 \%$ & 1461 & 6935 & 13.76 & 0.77 & 5.65 & 1501 & 7035 & 13.49 & 0.74 & 5.71 \\
\hline & Perlite & 708 & 3709 & 13.51 & 0.74 & 5.38 & 711 & 3685 & 13.42 & 0.72 & 5.46 \\
\hline & $P .90 \%+V 10 \%$ & 1152 & 5250 & 13.83 & 0.76 & 5.43 & 1176 & 5406 & 13.74 & 0.75 & 5.79 \\
\hline & P $80 \%+$ V $20 \%$ & 1346 & 6500 & 14.00 & 0.74 & 5.44 & 1418 & 6625 & 13.74 & 0.75 & 5.78 \\
\hline & P $70 \%+V 30 \%$ & 1458 & 6656 & 14.27 & 0.73 & 5.46 & 1485 & 6778 & 14.00 & 0.74 & 5.77 \\
\hline & L.S.D at 0.05 & 91.6 & 282 & 0.34 & n.s & 0.13 & 118 & 421 & 0.314 & n.s & 0.114 \\
\hline \multirow{8}{*}{ חִ } & Sand & 728.0 & 3631 & 14.00 & 0.75 & 5.33 & 734 & 4016 & 13.50 & 0.78 & 5.53 \\
\hline & $\mathrm{S.90 \%}+\mathrm{V} 10 \%$ & 1347 & 6877 & 14.00 & 0.78 & 6.23 & 1487 & 7304 & 13.75 & 0.80 & 6.48 \\
\hline & S $80 \%+$ V $20 \%$ & 1446 & 7347 & 13.75 & 0.80 & 5.53 & 1594 & 7259 & 14.00 & 0.75 & 6.45 \\
\hline & S $70 \%+V 30 \%$ & 1605 & 7684 & 14.00 & 0.80 & 6.45 & 1675 & 7573 & 13.75 & 0.80 & 6.18 \\
\hline & Perlite & 784.0 & 3984 & 14.00 & 0.80 & 5.40 & 813 & 3920 & 14.00 & 0.73 & 5.50 \\
\hline & P.90\%+V 10\% & 1320 & 6119 & 14.25 & 0.80 & 5.63 & 1382 & 6359 & 14.00 & 0.80 & 6.15 \\
\hline & P $80 \%+$ V $20 \%$ & 1515 & 6834 & 14.00 & 0.78 & 5.25 & 1671 & 7019 & 13.50 & 0.78 & 6.23 \\
\hline & P 70\% + V 30\% & 1702 & 7683 & 14.00 & 0.78 & 5.63 & 1765 & 7517 & 14.00 & 0.75 & 6.25 \\
\hline \multirow{8}{*}{ نَّ } & Sand & 617.0 & 3374 & 13.75 & 0.70 & 4.55 & 607 & 3285 & 13.00 & 0.75 & 5.15 \\
\hline & $\mathrm{S} .90 \%+\mathrm{V} 10 \%$ & 1504 & 6375 & 13.00 & 0.75 & 5.28 & 1540 & 6469 & 13.00 & 0.75 & 5.20 \\
\hline & S $80 \%+$ V $20 \%$ & 1592 & 6599 & 13.50 & 0.75 & 5.45 & 1581 & 6438 & 13.50 & 0.73 & 6.23 \\
\hline & $\mathrm{S} 70 \%+\mathrm{V} 30 \%$ & 1372 & 6250 & 13.50 & 0.75 & 5.28 & 1424 & 6268 & 13.25 & 0.73 & 5.45 \\
\hline & Perlite & 648.0 & 3451 & 13.25 & 0.68 & 5.48 & 652 & 3516 & 13.00 & 0.73 & 5.35 \\
\hline & P.90\%+V 10\% & 1196 & 5536 & 13.25 & 0.73 & $\mathbf{5 . 5 0}$ & 1223 & 5597 & 13.50 & 0.70 & 5.63 \\
\hline & P $80 \%+$ V $20 \%$ & 1373 & 5972 & 14.00 & 0.73 & 5.50 & 1428 & 5816 & 14.00 & 0.75 & 5.63 \\
\hline & P 70\% + V 30\% & 1393 & 5993 & 14.50 & 0.73 & 5.48 & 1401 & 6509 & 14.00 & 0.73 & 5.60 \\
\hline \multirow{9}{*}{ بִ } & Sand & 839.0 & 4610 & 13.63 & 0.72 & 5.01 & 905 & 5164 & 13.42 & 0.71 & 4.55 \\
\hline & $\mathrm{S.90 \%}+\mathrm{V} 10 \%$ & 1413 & 5852 & 13.25 & 0.73 & 5.28 & 1403 & 5937 & 13.23 & 0.75 & 5.51 \\
\hline & S $80 \%+$ V $20 \%$ & 1443 & 6895 & 13.30 & 0.74 & 5.45 & 1480 & 6995 & 13.15 & 0.74 & 5.34 \\
\hline & S $70 \%+V 30 \%$ & 1407 & 6872 & 13.77 & 0.77 & 5.22 & 1403 & 7265 & 13.48 & 0.71 & 5.52 \\
\hline & Perlite & 692.0 & 3692 & 13.28 & 0.75 & 5.25 & 669 & 3621 & 13.25 & 0.72 & 5.53 \\
\hline & P.90\%+V 10\% & 940.0 & 4094 & 14.00 & 0.74 & 5.15 & 924 & 4261 & 13.73 & 0.75 & 5.59 \\
\hline & P $80 \%+$ V $20 \%$ & 1150 & 6695 & 14.00 & 0.71 & 5.58 & 1155 & 7041 & 13.73 & 0.72 & 5.48 \\
\hline & P $70 \%+$ V 30\% & 1278 & 6292 & 14.30 & 0.70 & 5.27 & 1289 & 6308 & 13.99 & 0.75 & 5.47 \\
\hline & L.S.D at 0.05 & 110 & 413 & 0.50 & 0.077 & 0.18 & 110 & 616.3 & 0.163 & 0.0774 & 0.167 \\
\hline
\end{tabular}

Sand $90 \%$ : vermicompost $10 \%$, sand $80 \%$ : vermicompost $20 \%$, sand $70 \%$ : vermicompost $30 \%$, perlite $90 \%$ : vermicompost $10 \%$, perlite $80 \%$ : vermicompost $20 \%$, perlite $70 \%$ : vermicompost $30 \%$. 
Such increments in produced pods yield and its quality as a result of the application of chemical nutrient solution may be attributed to the presence of nutrient elements in balanced and mineral form more available to absorb by plants. Obtained results are in agreement with those reported by George et al., 2007, Gutiérrez-Miceli et al., 2008, Abou-El-Hassan et al., 2008.

As for the effect of different tested substrates, the same data in Table 7 indicate that addition of vermicompost at different used ratios to both sand and perlite significantly increased all measured yield and its traits compared with using sand and perlite alone without addition (control).

In this respect, adding vermicompost to both sand and perlite at rate of 20 or $30 \%$ reflected the highest values in all determined pods yield and its quality traits. In addition, using the mixture of sand with vermicompost was more superior compared with the substrate mixture of perlite plus vermicompost. Obtained results are similar to those reported by Ramachandra et al., (1998) on peas, Arancon et al., (2002) on tomato and (Arancon et al., 2004) on strawberry.

In addition, there is evidence that vermicompost added to plant media increases growth, flowering and fruiting of vegetables; Atiyeh et al., 2000a showed the highest yield on tomatoes when Metro-Mix 360 was mixed with $20 \%$ pig manure vermicompost and some field crops also show an increase in vegetable growth at low application rates of vermicompost (20 or 30\%) reverse that using higher rate from 40: $100 \%$. Mentioned by Arancon et al., 2008, Amir and Fouzia, 2011 on Pisum sativum and Abul-Soud et al., (2014a) on peas. With regard to the effect of the interaction, the same data reveal that using chemical nutrient solution combined with substrate of perlite or sand with the addition of vermicompost at the highest used rate of $20 \%$ or $30 \%$ exhibited the highest values in all determined yield parameters during both seasons of study. These results are in agreement with Senthilkumar et al., 2004 on rose.

\section{Conclusion}

The sustainment management of organic urban wastes could be performed sustainable source of substrate amendment and nutrient solution as a worm compost and vermi-liquid respectively. The further objective of mitigate greenhouse gases (GHG) save environment, nutrient resource and essential nutrients, Achieving by vermicomposting technique implementation. The recommended under these study could be summarized in using sand was more economical effusion than perlite and the best rate of applied vermicompost was $20 \%$, (sand+ vermicompost $(80+20 \mathrm{v} / \mathrm{v}))$ with nutrient solution.

\section{Acknowledgment}

This study was promoting by the activities of " Integrated environmental management of urban organic wastes using vermicomposting and green roof (VCGR) project" funded by Science and Technology Development Fund, Egypt by providing the vermicompost.

\section{References}

Abou-El-Hassan, S., U. A. El-Behairy, S. M. Selim and A. F. Abou-Hadid. 2008. Effect of compost tea as organic nutrient solution for cantaloupe production grown in nutrient film technique. Egypt. J. Hort. 35: in press.

Abul-Soud, M., M. K. Hassanein., S.M. Ablmaaty., M. Medany and Abu-Hadid A.F. 2009. Vermiculture and vermicomposting technologies use in sustainable agriculture in Egypt, Egypt. J. Agric. Res., 87 (1).

Abul-Soud, M, A., K.M. Refaie and R.E. Abdelraouf. 2014a. Influence of vermicompost and plant density on sustainable production of peas. Arab Univ. J. Agric. Sci., 22(1)55 -65.

Abul-Soud, M. A., M. S. A. Emam, M. A. A. Abdrabbo and Hashem. F. A. 2014b. Sustainable Urban Horticulture of Sweet Pepper via Vermicomposting in Summer Season, Journal of Advances in Agriculture 3, (1) 110-122

Allen, S. E. 1974. Chemical Analysis of Ecological Materials. Black-Well, Oxford, p: 565.

Amir Khan and Fouzia Ishaq 2011. Chemical nutrient analysis of different composts (Vermicompost and Pit compost) and their effect on the growth of a vegetative crop Pisum sativum. Asian Journal of Plant Science and Research, 1 (1):116-130.

Arancon, N. Q., C. A. Edwards., P. Bierman., J. Metzger., S. Lee and C. Welch. 2002. Applications of vermicomposts to tomatoes and peppers grown in the field and strawberries grown under high plastic tunnels. Proceedings of the International Earthworm Symposium, Cardiff Wales September 2002.

Arancon, N. Q, C. A. Edwards, P. Bierman., C. Welch and J. D. Metzger 2004b. Influences of vermicomposts on field strawberries-1: Effects on growth and yields; Bioresource Technology, 93: 145-153.

Atiyeh, R. M., N.Q Arancon., C. A. Edwards and J. D Metzger. 2000a. Influence of earthwormprocessed pig manure on the growth and yield of 
green house tomatoes. Bioresource Technology, 75, 175-180.

Atiyeh, R. M, S. Subler, C. A. Edwards., G. bachman, J. D. Metzger, and W. Shuster. 2000b. "Effects of vermicomposts and composts on plant growth in horticultural container media and soil". In Pedo biologia, 44: 579-590.

Atiyeh, R.M., Edwards, C.A., Subler, S and J., Metzger. 2001. Pig manure vermicompost as a component of a horticultural bedding plant medium: effects on physicochemical properties and plant growth. Bioresource Technology 78, 1120.

Bachman, G.R and J. D, Metzger. 2007. Physical and chemical characteristics of a commercial potting substrate amended with vermicompost produced from two different manure sources. Hort Technology 17(3), 336-340.

Chapman, H. D. and P. F. Pratt. 1961. Methods of analysis for soil, plant, and water. University of California, Division of Agric Sci.

Chanda, G.C., Bhunia G and S.K. Chakraborty. 2011. The effect of vermicompost and other fertilizers on cultivation of tomato plants. J. of Horticulture and Forestry 3 (2): 42-45.

Cooper, A. J. 1979. The ABC of NFT. Grower Books, London

Datt, N., Y. P. Dubey and Ch. Rohina. 2013 Studies on impact of organic, inorganic and integrated use of nutrients on symbiotic parameters, yield, and quality of French-bean (Phaseolus vulgaris L.) vis-à-vis soil properties of an acid alfisol. African Journal of Agricultural Research, 8(22), pp. 26452654.

Diver, S. 2002. Compost Teas for Plant Disease Control, ATTRA 1-800-346-9140.

El Behairy, U.A .1994. The effect of levels of phosphorus and zinc in the nutrient solution on macro and micronutrients uptake and translocation in cucumber (Cucumus sativus L.) grown by nutrient film technique. $\mathrm{PhD}$ Thesis, London Univeristy p: 299.

Ernst, G., A. Müller., H. Göhler and C. Emmerling. 2008. $\mathrm{C}$ and $\mathrm{N}$ turnover of fermented residues from biogas plants in soil in the presence of three different earthworm species (Lumbricus terrestris, Aporrectodea longa, Aporrectodea caliginosa). Soil Biology and Biochemistry. 40:1413-1420.

F. A. O. 1980. Soil and Plant Analysis. Soils Bulletin, 38: $242-250$.

Fernández-Luqueño F., V. Reyes-Varela., C. Martínez-Suárez., G. Salomón- Hernández., J. Yáñez-Meneses., J. M. Ceballos-Ramírez and L. Dendooven. 2010. Effect of different nitrogen sources on plant characteristics and yield of common bean (Phaseolus vulgaris L.). Biores. Technol., 101: 396-403.

Garg, V. K and P. Kaushik 2005. Vermi stabilization of textile mill sludge spiked with poultry droppings by an epigeic earthworm Eisenia foetida. Biores. Technol., 96: 1063-1071.

George, S., R. S. Giraddi and R. H. Patil. 2007. Utility of Vermiwash for the Management of Thrips and Mites on Chilli (Capsicum annuum L.) Amended with Soil Organics, Karnataka J. Agric. Sci., 20(3): (657-659).

Gutierrez-Miceli, F., Santiago-Borraz. J., Montes Molina. J., Nafate, C., Abdu-ArchilaM., OlivaLlaven M., Rincon- Rosales R., L and Dendooven 2007. Vermicompost as a soil supplement to improve growth, yield and fruit quality of tomato (Lycopersicum esculentum). Bioresource Technol. 98(15): 2781-2786.

Gutiérrez-Miceli, F.A., M.A. Oliva-Llaven, P.M Nazar, B. Ruiz-Sesma, J.D. Alvarez-Solís, L. Dendooven. 2011. Optimization of Vermicompost and Worm-Bed Leachate for the Organic Cultivation of Radish. Journal of Plant Nutrition. 34 (11): 1642-1653.

Gutiérrez-Miceli, F.A., R. C. García-Gómez., R. Rincón Rosales., M. Abud-Archila., O. L. María Angela., M. J. G. Cruz and L. Dendooven. 2008. Formulation of a liquid fertilizer for sorghum (Sorghum bicolor L.) Moench using vermicompost leachate, Bioresource Technology., 99 (14), 6174-6180.

Hashemimajd, K., Kalbasi, M., Golchin, A., and Shariatmadari. H. 2004. Comparison of vermicompost and composts as potting media for growth of tomatoes, Journal of Plant Nutrition, 27: pp. 1107-1123.

Hidalgo, P.R., F.B. Matta and R.L. Harkess. 2006. Physical and chemical properties of substrates containing earthworm castings and effects on marigold growth. Hort Science, 41, 1474-1476.

Inbar, Y., Y Chen and Y. Hadar. 1993. Recycling of cattle manure: The composting process and characterization of maturity. Journal of Environmental Quality, 22: 875-863.

Kamergam, N., K. Alagumalai and T. Daniel 1999. Effect of vermicompost on the growth and yield of green gram (Phaseolus aurus Roxb.). Trop. Agric., 76: 143-146.

Karuna, Sh, Pramod, S., Eric M A., Kerry B W., Keith H. and Andrew S B. 2011. Changes in microbial and nutrient composition associated with rumen content compost incubation, Bioresource Technology, 102, 3848-3854.

Kumari, M.S. and K. Ushakumari. 2002. Effect of vermicompost enriched with rock phosphate on the yield and uptake of nutrients in cowpea (Vigna 
unguinculata L. WALP). J. Trop. Agric., 40: 2730.

Manivannan, S., $\quad$ M. Balamurugan., K. Parthasarathi., G. Gunasekaran and L. S. Ranganathan, 2007. Effect of vermicompost on soil fertility and crop productivity of beans (Phaseolus vulgaris), J. Environ. Biol.: 30(2), 275281.

Monroy F, M. Aira and J. Domínguez. 2009. Reduction of total coli form numbers during vermicomposting is caused by short-term direct effects of earthworms on microorganisms and depends on the dose of application of pig slurry. Science of the Total Environment; 40(7):54115416.

Nath G., Keshav, Singh and D.K .Singh. 2009. Chemical Analysis of Vermicomposts / Vermiwash of Different Combinations of Animal, Agro and Kitchen Wastes. Australian Journal of Basic and Applied Sciences, 3(4): 3671-3676

Pant A. P., T.J.K. Radovich, N. V. Hue, S.T. Talcott and K.A. Krenek. 2009. Vermicompost extracts influence growth, mineral nutrients, phytonutrients and antioxidant activity in pak choi (Brassicarapa cv. Bonsai, Chinensis group) grown under vermicompost and chemical fertilizer. Journal of Science of Food and Agriculture. 89 (14): 23832392.

Quaik, S.A. Embrandiri, P. F. Rupani, R. P. Singh and M. H. Ibrahim. (2012a). Effect of Vermiwash and Vermicomposting Leachate in Hydroponics Culture of Indian Borage (Plectranthus ambionicus) Plantlets. UMT 11th International Annual Symposium on Sustainability Science and Management. e-ISBN 978-967-536693-2: 210-214

Quaik, S.A. Embrandiri, P. F. Rupani and M. H. Ibrahim. 2012b. Potential of Vermicomposting Leachate as Organic Foliar Fertilizer and Nutrient Solution in Hydroponic Culture: A Review. 2nd International Conference on Environment and BioScience IPCBEE vol.44 pp 43-47

Ramachandra, R., M. A. N Reddy., Y. T. N Reddy., N. S Reddy., M. Anjanappa., and R. Reddy. 1998. Effect of organic and inorganic sources of NPK on growth and yield of pea (Pisum sativum). Legume Research 21: 57-60.

Raul, I, C. 1996. Measuring physical properties. Rutgers Cooperative Extension. New Jersey Agriculture Experiment Station. New Jersey University.

Rasool, A., T. G. Mousa and H. Behzad. 2009. The effect of sheep-manure vermicompost on quantitative and qualitative properties of cucumber (Cucumis sativus L.) grown in the greenhouse.
African Journal of Biotechnology Vol. 8: 49534957

Roy, S, K. Arunachalam., D. B. Kumar and A. Arunachalam. 2010. Effect of organic amendments of soil on growth and productivity of three common crops viz. Zea mays, Phaseolus vulgaris and Abelmoschus esculentus. Appl.Soil.Ecol. 45:78-84.

Scheuerell, S. and W. Mahaffee 2002. Compost Tea: Principals and prospects for plant disease control. Compost Science \& Utilization 10(4): 313-338.

Senthilkumar, S, M.V. Sriramach, Rasekharan and K. Haripriya 2004. Effect of vermicompost and fertilizer on the growth and yield of rose. J. Inter Acad, 8: 207-210.

Sharma, S., Y. P. Dubey., B. P. Kaistha., T. S. Verma. 2008. Rhizobium and phosphorus interaction on N-P uptake by French bean (Phaseolus vulgaris,L) in an acid Alfisol from northwest Himalayan region. J. Indian Soc. Soil Sci. 56:118-122.

Singh, N. I and J.S. Chauhan 2009 Response of French bean (Phaseolus Vulgaris L.) To Organic Manures and Inorganic Fertilizer on Growth \& Yield Parameters Under Irrigated Condition Nature and Science; 7(5), ISSN 1545-0740

Singh, R., P. K. Gupta., R. T. Patil., R. Sharma., R. Asrey., A. Kumar and K. Jangra. 2010. Sequential foliar application of vermicompost leachates improved marketable fruit yield and quality of strawberry (Fragaria x ananassa Duch). Hort. Sci. 124: 34-39.

Snedecor, G. M. and W. G. Cochran. 1980. Statistical methods, Sixth Edition, Lowa State Univ. Press, Amer. Lowa, USA

Surrage, V. A., Lafrenière $C$., Dixon $M$ and $Y$. Zheng. 2010. Benefits of vermicompost as a constituent of growing substrates used in the production of organic greenhouse tomatoes // Hort Science. 45 , p. $1510-1515$

Suthar, S. 2009. Impact of vermicompost and composted farm yard manure on growth and yield of garlic (Allium stivum L.) field crop.International J. of Plant Production 3; 27-38.

Tejada, M., I. Gomez., T. Hernandez and C. Garcia 2010. Utilization of vermicomposts in soil restoration: effects of soil biological properties, Soil Sci. Soc. Am. J, 74: 525-532.

Venugopal, A; M. Chandrasekhar., B. V. Naidu and S. Raju. 2010. Vermicomposting in sericulture using mixed culture of earthworms (Eudrillus eugineae, Eisenia foetida and Perionyx excavates) - A review. Agricultural Reviews, 31(2): 150-154.

Veerabhadraiah, T., N. Chamegowda and T. C. Badrinath. 2006. Effect of organic and inorganic 
sources of nutrients on avilabality and uptake of major and secondary nutrients by French bean in eastern dry zone of karnataka, India (Phaseolus vulgaris L.). The 18th World Congress of Soil Science, 115-49.

Watanabe, F. S. and S. R. Olsen. 1965. Test of an ascorbic acid method for determining phosphorus in water and $\mathrm{NaHCO} 3$ extracts from soils. Soil Sci. Soc. Am. Proc.29: 677-678.

Wilson, G. C. S. 1983. The physic- chemical and physical properties of horticultural substrate. Acta Hort 150: 19-32

Yadav K. D., V. Tare and M. M. Ahammed. 2010. Vermicomposting of source-separated human feces for nutrient recycling. Waste Management; 30:50-56. 


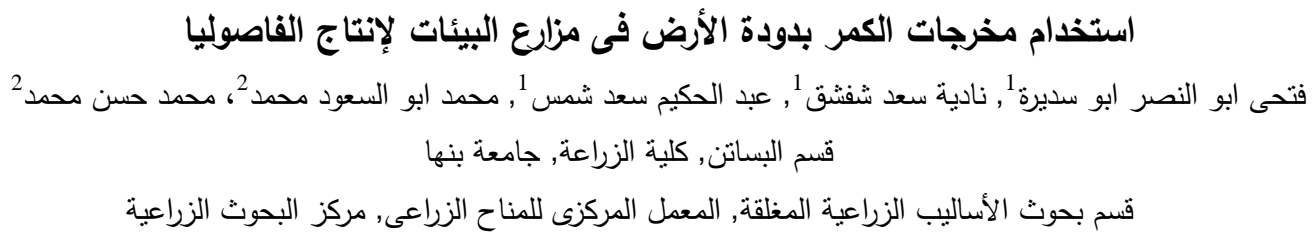

تم اجراء التجربة خلال الموسم النيلى 2012-2013 / 2013- 2014بموقع الزراعة المحمية بالدقى الدعل المركزى للمناخ الزراعى -

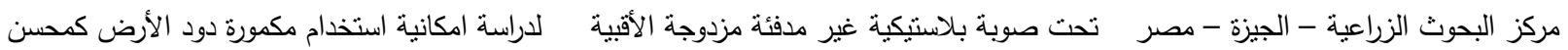

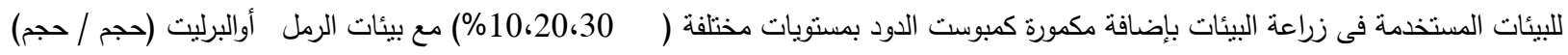
مقارنة بالكنترول ( بدون اضافة) وكذلك تاثير استخدام سائل دود الأرض و شاى الكمبوست كمحاليل مغذيه بالمقارنة بالمحلول المغذى المعدنى وكنلك

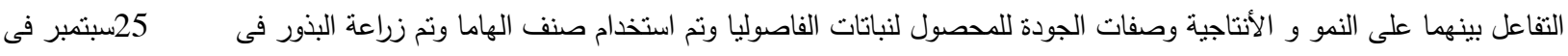

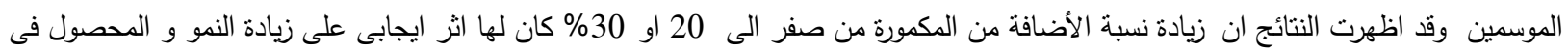

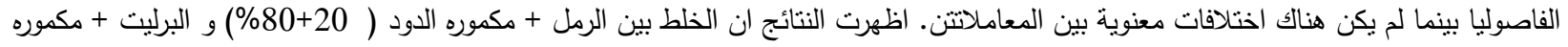

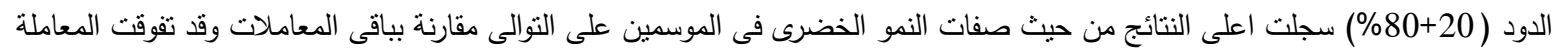

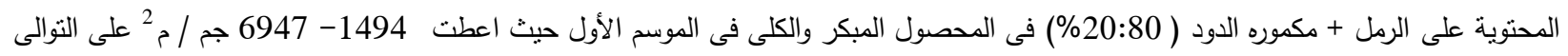

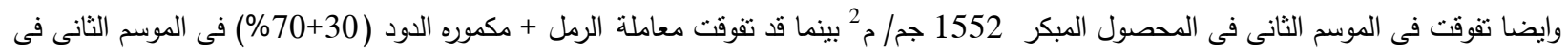

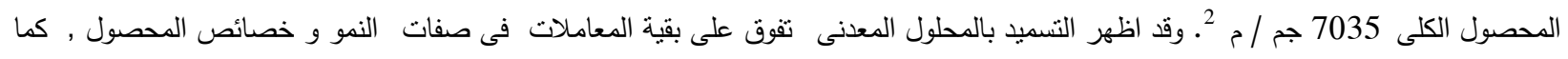

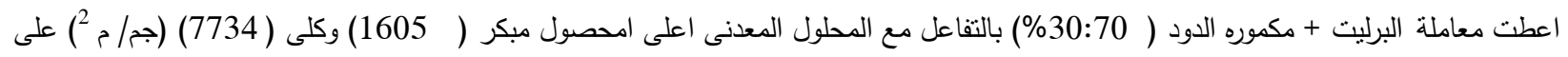

